\title{
Insight into the Adaptability of Dominant Plant Indigofera amblyantha Craib for Ecological Restoration of Rock Slopes in Stone Coal Mine
}

\author{
Lu Peng $\mathbb{D}^{1,2}$ Qiming Mao $\mathbb{D}^{1},{ }^{1}$ Lin-Ying Cao $\mathbb{D}^{1},{ }^{1}$ Hailong Sun $\mathbb{D},{ }^{3}$ Xiande Xie $\mathbb{D}^{1}$, \\ and Shuang Luo $\mathbb{D}^{1}$ \\ ${ }^{1}$ College of Resources and Environment, Hunan Agricultural University, Changsha 410128, China \\ ${ }^{2}$ College of Biology and Environmental Sciences, Jishou University, Jishou 416000, China \\ ${ }^{3}$ State Key Laboratory of Hydraulics and Mountain River Engineering, Sichuan University, Chengdu 610065, China \\ Correspondence should be addressed to Xiande Xie; xd_xie@hunau.edu.cn and Shuang Luo; shuangluo@hunau.edu.cn
}

Received 10 September 2021; Revised 7 October 2021; Accepted 8 October 2021; Published 1 November 2021

Academic Editor: Hai-Bo Qin

Copyright @ $2021 \mathrm{Lu}$ Peng et al. This is an open access article distributed under the Creative Commons Attribution License, which permits unrestricted use, distribution, and reproduction in any medium, provided the original work is properly cited.

\begin{abstract}
The eco-restoration was a very effective measure to solve the problem of environmental pollution caused by the exposed mine surface in the stone coal mine site. In this study, the dominant plant, Indigofera amblyantha Craib, was well adapted to the eco-restoration in stone coal mining area. The changes of nutrient elements, $\mathrm{pH}$, heavy metals in substrate material, the biological concentration/transfer factor, and the distribution and diversity of bacteria and fungi in rhizosphere soil were investigated. The results show that the plant communities help slow down the loss of nutrient elements and the increase of the concentrations of heavy metals in the eco-restoration process. The Indigofera amblyantha Craib had the advantaged ability to enrich and transfer $\mathrm{Cd}, \mathrm{Cu}, \mathrm{Mn}$, and its diversity index of microbial communities in rhizosphere soils was higher than that of other quadrats. These excellent properties found in this work help reveal the insight into the adaptability of Indigofera amblyantha Craib in the eco-restoration of stone coal mines. It is valuable to evaluate Indigofera amblyantha Craib for eco-restoration engineering of stone coal mine and extend the application in heavy metal contaminated sites.
\end{abstract}

\section{Introduction}

Stone coal is a kind of combustible with the characteristics of low-carbon, low-calorific, high-ash, and high-sulfur [1, 2]. The constituents of stone coal are complex associated with polymetallic composition [3,4]. Thus, stone coal is an important resource of vanadium (V) [2]. More than $87 \mathrm{wt} . \%$ of the domestic reserve of $\mathrm{V}$ came from stone coal in China [5]. V has been widely used in chemical industries, metallurgy, atomic energy, aviation, and so on [6-8]. Then, the increasing demand for $\mathrm{V}$ led to the intensification of the exploitation of stone coal mines $[9,10]$, which formed a lot of bare slopes and waste piles exposed to the air. The acidic mine discharge (AMD) was formed when these bare minerals oxidized by oxygen and came into contact with the rainwater $[11,12]$. The AMD could future dissolve some heavy metals discharged into water $[13,14]$. The leaching concentration of heavy metals from stone coal was largely dependent on solution $\mathrm{pH}$ [15], the $10.41 \% \mathrm{Cd}$, and $0.07 \%$ $\mathrm{Pb}$ could be released from stone coal over 7 days in $\mathrm{pH} 3.5$ [16]. For the fine particle sizes of stone coal, the dissolved rates of $\mathrm{Pb}, \mathrm{As}, \mathrm{Cd}$, and $\mathrm{V}$ were $0.95 \%, 2.96 \%, 0.25 \%$, and $0.35 \%$ after 100 days in $\mathrm{pH} 4.5$ solution, respectively [17]. These heavy metals further hazarded surrounding farmland and rivers, which caused the environmental situation of sites around stone coal wastes was not optimistic [18]. Thus, it was an urgent need to solve the problem of environmental pollution in the stone coal mine site.

The eco-restoration was a very effective measure to prevent AMD formation and to green the exposed mine surface [19-21]. However, due to lack of the conditions of water, nutrients, and soil layer for plant growth, and with 
the extreme microclimatic, edaphic conditions, and heavy metals pollution, it was difficult for eco-restoration of exposed rocky slope in the stone coal mine [21-27]. Cutting and sorting slopes, covering soil, and planting plants were the main methods at present [28-30]. The growth status of plants was an important criterion for measuring ecological restoration. Thus, selecting tolerant plant species was essential to ecological restoration. For example, Cynodon Dactylon (L.) Pers., Paspalum paspaloides, and Zoysia japonica Steud are used in slope vegetation restoration in East China. Robinia pseudoacacia L. and Indigofera amblyantha Craib were used in the slope of roads and railways for ecological restoration $[31,32]$. These plants had the characteristics of strong drought tolerance and resistance to infertility. In addition, Indigofera amblyantha Craib was used in the tungsten mine site for ecological restoration [33] and was found that had the moderate tolerance and bioaccumulation capability for $\mathrm{Pb}$ and $\mathrm{Cd}[34,35]$. However, the drought, loss of nutrients, and heavy metal stress were the important limiting factors on these sites for plant establishment [36]. But there were still plants that can grow tenaciously in extreme environments. Therefore, these plants had unique adaptability to unfavorable environments.

In this study, we firstly found that Indigofera amblyantha Craib grow well in stone coal mine slope after artificial eco-restoration and was the dominant plant in all shrubs. However, there was a lack of research on the adaptation of Indigofera amblyantha Craib to heavy metal contaminated sites and its tolerance to heavy metals. Therefore, the growth of Indigofera amblyantha Craib was closely related to the effect factors and the distribution of heavy metals in soil, which help understand the adaptability of Indigofera amblyantha Craib. As a result, these findings help guide the eco-restoration engineering of the stone coal mine.

\section{Materials and Methods}

2.1. Study Sites and Ecological Engineering. The site of ecological restoration engineering of stone coal mine was in Nijiang Kou, Yiyang City, Hunan province. The area belongs to the subtropical humid continental monsoon climate. The total area of the ecological restoration engineering was about $75,000 \mathrm{~m}^{2}$, and the construction was completed in March 2019. In this study, the representative area of $3,000 \mathrm{~m}^{2}$ was selected as the study area to future analyze the changes in the recovery process.

The ecological restoration engineering was adopted the thick layer substrate material spraying after hanging net for vegetation restoration [37]. The ecological engineering is carried out sequentially in accordance with the process of galvanized wire mesh fastened, herbaceous fibers added to mesh, substrate material and seeds sprayed, and nonwoven fabric covered. A detailed description of the ecological restoration engineering was shown in Text S1 Supplementary Information (SI).

2.2. Materials Used in Ecological Engineering. The substrate material was composed of a variety of material mixing, including soil, peat soil, sawdust, organic fertilizer, com- pound fertilizer, aggregate agent, water retention agent, biobacterial manure, and seed according to a certain proportion (Table S1). The soil was sticky laterite (particle size $\leq 0.5 \mathrm{~cm}$, water content $\leq 30 \%$ ) without stones or gravel. The peat soil and sawdust were used to improve the soil structure and increase the content of organic matter, water conservation, and prevent loss. The organic fertilizer is the product of pig manure fermentation (organic matter content $\geq 30 \%$ ). The compound fertilizer could provide nitrogen, phosphorus, and potassium for plant growth (China Agricultural Materials Group, $N \geq 18 \%, P \geq 18 \%$, and $K \geq 18 \%$ ). The aggregate agent could improve soil structure and promote oxygen supply (provided by Hunan ZhiLan Ecological Environment Construction Co. Ltd.). The soil water retention agent was anionic polyacrylamide (PAM) (Shanghai Wshine Chemical Co., Ltd., Shanghai, China, particle diameter $0.02 \mathrm{~mm}$, the active ingredient concentration 99.9\%). The biobacterial manure could accelerate the substrate material microbial life activities and improve the transformation of nutrients and plants to absorb nutrients.

The selection of plant species was based on reports in successful engineering from common rock slope and similar mine restoration [38-40]. Table S2 listed the selected plant species and densities used well applied in rocky slopes ecoengineering.

2.3. Sample Collection and Analysis. The investigation time lasted for 2 years after eco-restoration. Twelve samples were established at four different locations in the study area to assess plant species and communities in eco-engineering restoration. The Indigofera amblyantha Craib was the dominant species in the fruticose community due to it had the highest importance value (IV) (detail see Text S2), which could reflect the position and function of a species in a given community [41]. The sampling and handing methods of substrate material and plants (root, leaf, stem xylem, stem phloem, and fruit/seed) saw Text S3.

The $\mathrm{pH}$, total nitrogen (TN), total phosphorus (TP), total potassium (TK), total organic carbon (TOC), hydrolyzable nitrogen ( $\mathrm{HN})$, available phosphorus (AP), and available potassium $(\mathrm{AK})$ of substrate material samples were analyzed. The $\mathrm{pH}$ was determined by the potentiometry method. The organic matter (TOC) was measured by the potassium dichromate external heating method [42], and the total phosphorus (TP) and available phosphorus (AP) were determined by alkali fusion and sodium bicarbonate extraction Mo-Sb antispectrophotometric method, respectively $[43,44]$. The total nitrogen (TN) and hydrolysable nitrogen $(\mathrm{HN})$ were measured by the Kjeldahl nitrogen analysis method [45] and the alkali hydrolysis diffusion method [46]. The total potassium (TK) and available potassium (AK) were determined by atomic absorption spectrometry [47] and acetic acid extraction-flame photometric method [48]. The content of heavy metals, including $\mathrm{Pb}, \mathrm{Cd}, \mathrm{Cr}$, As, $\mathrm{Cu}, \mathrm{Zn}, \mathrm{Ni}, \mathrm{Sb}, \mathrm{Mn}$, and $\mathrm{V}$ in stone coal, artificial soil, and plants, were measured by ICP-OES (NexION 350X, PerkinElmer, USA) after digesting tissues following the Chinese National Standards for Food Safety Determination of multiple elements (GB5009. 268-2016). 
The composition of rhizosphere microorganisms also has a certain relationship with plant adaptability. For the extraction of bacteria and fungi to analyze microbial diversity, a part of substrate material sampling was stored at $-20^{\circ} \mathrm{C}$ at the twenty-first month (2020.12) after vegetation restoration. In addition, adjacent natural environment samples were supplemented, including bamboo forests, rice paddies, river shoal sediments, grasslands, exposed ditches, and stone coal. The microbial samples were then sent to Novogene Technology Co., Ltd (Beijing, China), and sequencing was analyzed based on the Illumina NovaSeq PE250 [49]. The results of species, clustering, and diversity analysis based on operational taxonomic units (OUTs) were provided by Novogene.

A redundancy analysis (RDA) was used to find out the positive or negative effect of environmental factors on the eco-restoration diversity by adopting CANOCO 5.0 [50].

\section{Result}

3.1. Nutrient Elements in the Substrate Material. Soil provided a substrate for the exchange of material and energy for plant growth and played an essential role in plant growth, especially in the process of ecological restoration [51-53]. First, the $\mathrm{pH}$ in substrate material was a clear drop starting from $6.56 \pm 0.54$ to $5.40 \pm 0.64$ and then gradually rose to about $6.10 \pm 0.89$ (Figure S1). The acid wastewater leached from the stone mine slope might be the dominant reason leading to $\mathrm{pH}$ decline $[54,55]$. Various metal sulfides in the stone coal mine were oxidized to sulfates in contact with atmospheric oxygen and rain, which caused $\mathrm{pH}$ to decrease in substrate material [56]. The vegetation in eco-engineering restoration prevented most oxygen from contacting sulfur compounds, which have slowed down the formation of AMD [57].

The HN, AP, and AK were significant decline trends with recovery time in the substrate material (Figure 1). The concentration of $\mathrm{HN}, \mathrm{AP}$, and $\mathrm{AK}$ were reduced by $63.4 \%, 94.8 \%$, and $83.1 \%$, respectively, from initiation. However, the $\mathrm{HN}$ and $\mathrm{AK}$ increased slightly in the twenty-first month. The total N, P, and $\mathrm{K}$ decreased by $49.7 \%, 73.8 \%$, and $45.7 \%$, respectively, from initial to the $18^{\text {th }}$ month. However, the rate of decline of TN, TP, and TK in the second year was significantly slower than that in the first year, and their concentrations began with upward trends from the $18^{\text {th }}$ to the twenty-first month. The rain and plant absorptions were the main driving factors in the decrease of HN, AP, and AK [58]. The small increase of HN and AK may be the decomposition of litterfall [59] or the degradation of slow-acting components such as organic fertilizers. It is worth noting that the TOC has been on the rise since the $6^{\text {th }}$ month. The TOC (twenty-first month) in the soil layer was 1.88 times higher than the initial content. $\mathrm{Hu}$ et al. and Liu et al. suggested that vegetation restoration was beneficial to increase the content of organic matter in the soil $[60,61]$. The reason may be that (1) the TOC in the soil layer was easily absorbed by the soil and peat in the matrix and less loss with water [62]; (2) the organic acids secreted by plant roots were accumulated in the soil

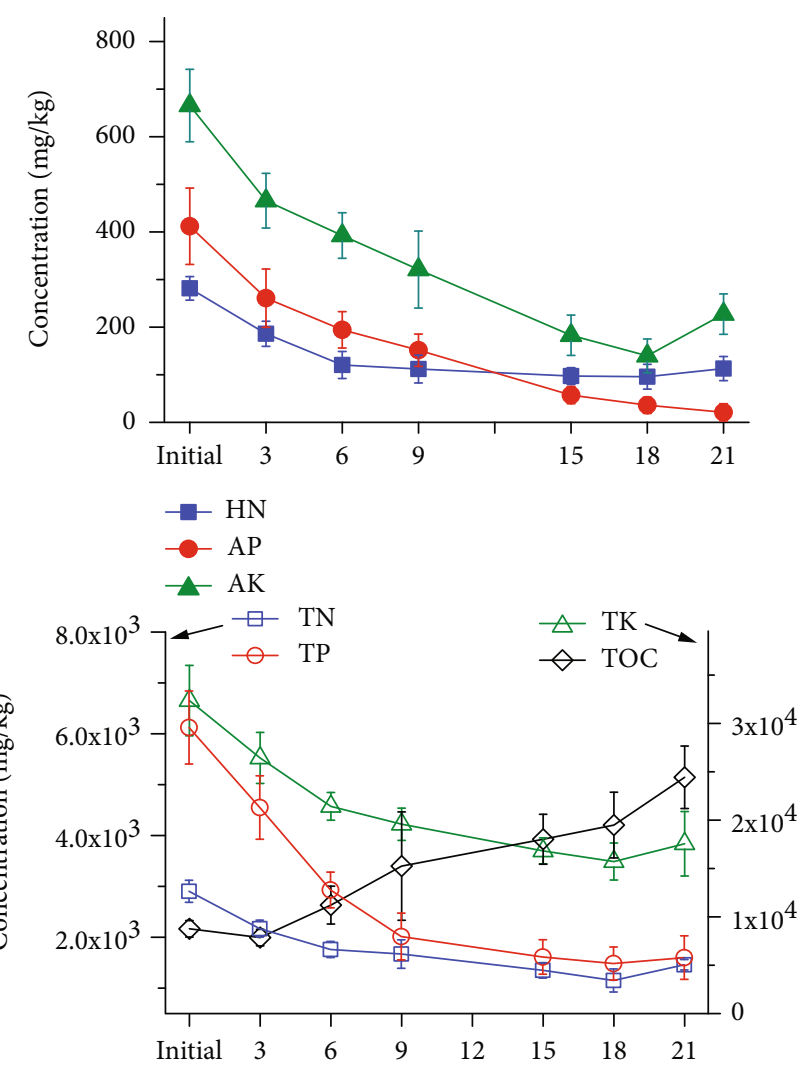

Figure 1: The N, P, K, and TOC in substrate material with the recovered times. The $\mathrm{HN}, \mathrm{AP}$, and $\mathrm{AK}$ were hydrolyzable nitrogen, available phosphorus, and available potassium; and TN, $\mathrm{TP}$, and TK were total nitrogen, total phosphorus, and total potassium, respectively.

$[63,64]$. It indicated that the restoration of vegetation was conducive to the increase of organic matter. The linear regression (LR) and nonlinear regression (binomial regression, BR) fitting results showed that there were significant positive correlations between $\mathrm{HN}$ and $\mathrm{TN}, \mathrm{AP}$ and $\mathrm{TP}$, and $\mathrm{AK}$ and TK (Figure S2). The high determination coefficients $\left(R^{2} 0.936-0.971\right.$ for LR and $0.955-0.981$ for BR, respectively) suggested that the contents between available states and total states were a close correlation, which indicated that the loss of $N, P$, and $K$ were mainly in the form of $\mathrm{HN}, \mathrm{AP}$, and $\mathrm{AK}$.

3.2. Changes of Heavy Metals in the Substrate Material. Despite, the bare stone coal has been covered by a layer of artificial substrate material, but there had still heavy metals leaching from stone coal in the early stages when there was rain and oxygen $[11,56]$. Thus, stone coal still was an important source of heavy metals, the concentrations of which were significantly higher than that of initial substrate material (init.), except Mn (Table S3). And the concentrations Mn were a downward trend from the initial to the $18^{\text {th }}$ month and then increased again. The possible reason was that the initial addition of quick-acting fertilizers contained high levels of $\mathrm{Mn}$, but it lost heavily in early recovery time. The changing 

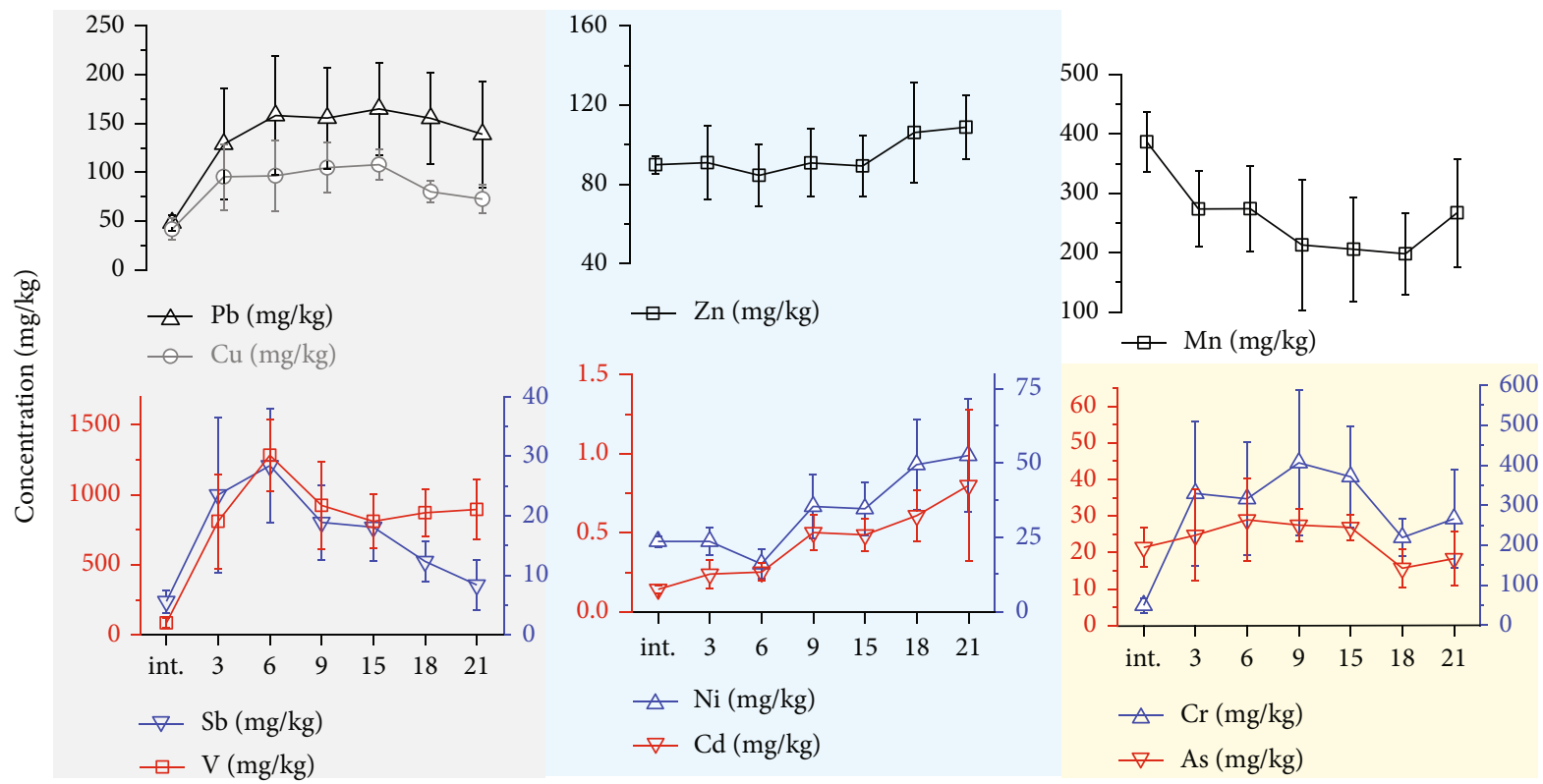

Recovered time (month)

FIgURE 2: The concentrations of heavy metal in initial substrate material (init.) with recovered time. The same background color indicates the same change trend.

trend of heavy metals in the substrate material can be divided into 3 groups (Figure 2): (1) first rises and then fall, as $\mathrm{Pb}, \mathrm{Cu}$, $\mathrm{Sb}$, and V; (2) increase overall, as $\mathrm{Zn}, \mathrm{Ni}$, and $\mathrm{Cd}$; (3) increase first, then decrease, then increase, as $\mathrm{Cr}$ and As. The reason may be these heavy metals of group with the similar physicochemical properties and environmental behaviors in artificial soil environments. The biological concentration factor (BCF) and biological transfer factor (BTF) of heavy metals (Text S4) showed that Indigofera amblyantha Craib had a stronger ability to enrich and transfer $\mathrm{Cd}, \mathrm{Cu}, \mathrm{Zn}$, and $\mathrm{Mn}$ and with a good tolerance to $\mathrm{Pb}, \mathrm{Sb}, \mathrm{V}$, and $\mathrm{Cr}$ (Figure S3). After being absorbed by roots in the soil, Cd, $\mathrm{Cu}$, and $\mathrm{Mn}$ were mainly transferred to leaves, while $\mathrm{Zn}$ was mainly accumulated in stem-phloem and roots. It suggested that Indigofera amblyantha Craib has a good tolerance to these heavy metals.

However, these changes of heavy metals in artificial substrate material were closely related to many factors, among them, the interaction of plants and microorganisms might be the important factor.

3.3. Microorganisms in the Substrate Material. The species distribution and diversity of bacteria and fungi were analyzed from 17 soil samples (Table S4) obtained from adjacent natural environments (R0, including bamboo forests, rice paddies, and river sediments), herbs and grasslands (R1) in eco-restoration, Indigofera amblyantha Craib rhizosphere soil (R2), other fruticose rhizosphere soil (R3), bare stone coal (R4), and gully formatted from artificial soil (R5). A total of 9801 OTUs were detected in the bacterial community, which were annotated to 82 phyla, 180 classes, 391 families, 547 orders, 905 families, 905 genera, and 1401 species. Most of them belong to Actinobacteria, Gemmatimonadetes, Acidobacteria, Proteobacteria, Chloroflexi, etc. For fungi, 2753 OTUs detected were attributed to 17 phyla, 66 classes, 172 orders, 370 families, 761 genera, and 1072 species, which mostly belong to the Ascomycota, Basidiomycota, Mortierellomycota, Chytridiomycota, etc.

In the relative abundance of the top 10 species in phylum and genus levels, there was a great difference among groups (Figure S4). Although Proteobacteria and Ascomycota occupied a significant proportion of each group of bacteria and fungi in the phylum levels, respectively, there were still differences in the distribution of species in phylum levels (Figure S4). The differences in the composition of species were especially evident at the genus level. For the ecorestoration groups (R1, R2, and R3), the rhizosphere microorganisms of different plant species were also significantly different. Combination with the heatmap analysis of bacteria and fungi species could further identify the dominant species. From the clustering heat map of bacteria and fungi at the genus level (Figure 3), there were significant differences in species clustering among groups. The species with great relative abundance were the dominant species in the groups.

For the bacteria, the abundance of Meiothermus, Occallatibacter, an uncultured Chloroflexi bacterium (named 1921-2), and Acidothermus was higher than other species in R0 group (natural environment). The Nitrosomonas, Candidatus Jettenia, and Candidatus Kuenenia were mainly species in the soil of herbs and grasslands samples (R1). The main species of bacteria in the rhizosphere soil of Indigofera amblyantha Craib samples (R2) were Gemmatimonas and Conexibacter Sphingomonas, and that of other fruticose samples (R3) were Pseudomonas, Flavobacterium, and Acidibacter. For the bare stone coal samples (R4) and exposed ditches formatted from the slope of recovered (R5), the main species were Granulicellas, Streptococcus and Acidiphilium, 


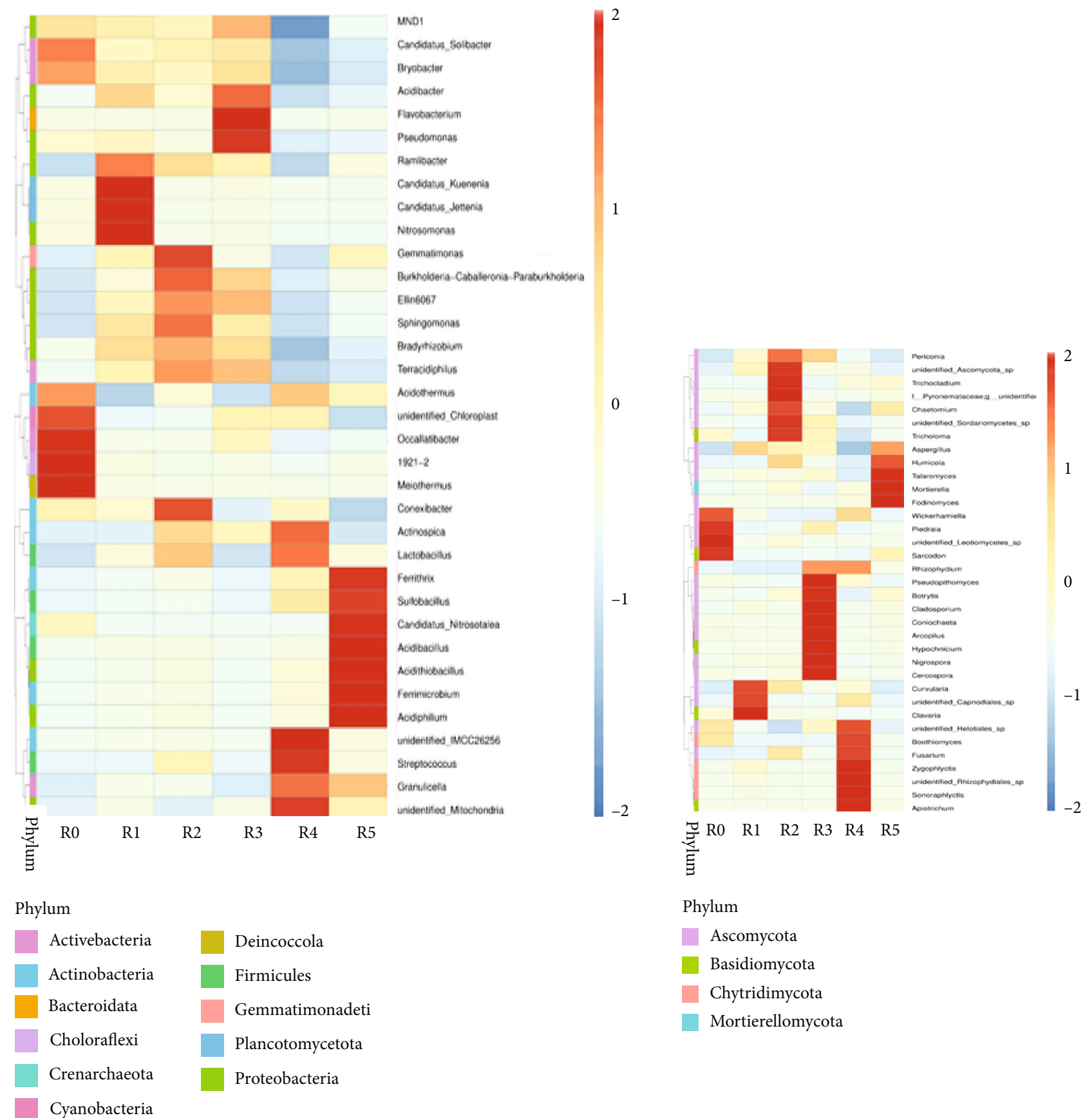

(a)

(b)

FIGURE 3: The heatmap analysis of bacteria and fungi species abundance clustering at the genus level. The genus classification position clustering (horizontal) and top 35 genera sample clustering (vertical clustering). Different color means the different relative abundance of the genus (red means great abundance).

Ferrimicrobium, Acidithiobacillus, Acidibacter, and Sulfobacillus, respectively.

The genus classification position clustering of fungi was more obviously different than bacteria among groups (Figure 3). The species of great relative abundance of R0 group were Wickerhamiella, Piedraia, and Sarcodon, and that of R1 group were Clavaria, Capnodicles, and Curvularia. For Indigofera amblyantha Craib samples group (R2), Tricholoma, Sordariomycetes, Chaetomium, Ascomycota, Periconia, Pyro- nemataceae, and Tricholadium were mainly genera, and Cercospora, Nigrospora, Hypochnicium, Arcopilus, Coniochaeta, Cladosporium, Botrytis, and Pseudopithomyces were mainly genera in R3 group. The main genera of fungi in R4 and R5 were concentrated in Fusarium, Apiotrichum, Sonoraphlyctis, Zygophlyctis, and Boothiomyces and Fodinomyces, Mortierella, Talaromyces, and Humicola, respectively.

The species abundance and classification position clustering reflected the dominant species among groups but 
did not reveal indicate differences in community structure and diversity [65]. Therefore, the Shannon-Wiener diversity index was used to analyze intergroup diversity (Figure S5). For the bacteria, the Shannon index of eco-restoration groups (R1, R2, R3) and adjacent natural environments (R0) were obvious higher than the bare stone coal samples (R4) and ditches (R5). However, for the fungi, the Shannon index of fruticose samples (R2 and R3) was higher than in other groups. The Shannon index of fungi in R4 and R5 groups was higher than that of bacteria. This shows that different environments and plant communities have a great influence on the composition of microorganisms. It is worth noting that the Shannon indexes of bacteria and fungi in Indigofera amblyantha Craib samples (R2) were at a higher level in all groups. The Indigofera amblyantha Craib as dominant species in eco-restoration had a great promoting effect on improving soil microbial diversity.

\section{Discussion}

4.1. Relationship between Community and Factors. The redundancy analysis (RDA) could identify the factors that had a greater impact on the plant species $[50,66]$. The longer the radiation of the environmental factor, the greater the influence of the factor. When the angle between different environmental factors and/or species was acute, it indicated a positive correlation, and on the contrary, obtuse represented a negative correlation between them [66-68]. The RDA analysis between IV of plant species and environmental factors ( $\mathrm{pH}$, nutrient elements, TOC, and heavy metals) is shown in Figure 4. The first two axes explained $76.4 \%$ of the microbial community variation (axis 1: $41.0 \%$, axis 2 : $35.4 \%)$. The total variation was 0.841 and $P=0.082$. The TOC, HN, AP, Sb, Cd, and V in the substrate material were the main environmental factors affecting the IV of plant species (Figure 4). The IV of Indigofera amblyantha Craib was a positive correlation with $\mathrm{HN}, \mathrm{AP}, \mathrm{V}$, and $\mathrm{Sb}$, and a negative correlation with TOC and Cd. It suggested that Indigofera amblyantha Craib growth was less affected by other factors, and the increase of $\mathrm{HN}, \mathrm{AP}$, and $\mathrm{Sb}$ will facilitate its growth.

4.2. Characteristics of Indigofera amblyantha Craib. Indigofera amblyantha Craib could grow well in poor and $\mathrm{pH}$ 4.5-7.5 soil due to the characteristics of resistance to infertility $[69,70]$. In addition, Indigofera amblyantha Craib has a strong drought tolerance [71, 72]. Under the conditions of water drought stress simulated by PEG (polyethylene glycol) solution as nutrient solution, the Indigofera amblyantha Craib seeds could germinate normally under the concentrations of $0-250 \mathrm{~g} \mathrm{~L}^{-1}$ PEG, and with $80.2 \%$ of the normal germination rate under the simulated drought condition of $150 \mathrm{~g} \mathrm{~L}^{-1}$ PEG [73]. The Indigofera amblyantha Craib could effectively prevent water loss and ensure its normal physiological activities under drought conditions [74]. The Indigofera amblyantha Craib also could reinforce the tensile and shear strength of roots-soil, which contributed to maintain the stability of eco-restoration in slope and prevent nutrient loss $[75,76]$. The tensile strength of root was $21.15-76.08 \mathrm{MPa}$ [77], and the maximum shear strength of root-soil was about $250 \mathrm{KPa}$ [78]. Thus, these characteristics of Indigofera amblyantha Craib determined its dominant position under adverse circumstances.

4.3. Indigofera amblyantha Craib and Microorganism. In addition, the bacteria and fungi as the biotic factors, it also affected the community composition and the plant species growth to some extent. It could be confirmed to a certain extent from the differences in abundance and clustering of microbial species in different groups (Figure 3 and S4), and the diversity of microorganisms was higher than that of other plant species (Figure S5). The root of Indigofera amblyantha Craib could form distinct nodules with the nitrogen fixation ability (Figure S6), which provided a certain nitrogen source for plant growth. $\mathrm{Xi}$ et al. confirmed that there had 12 species of rhizobium associated with the roots of Indigofera amblyantha Craib in rocky desertification area, Guizhou Province, China, the dominant genus was Bradyrhizobium [79]. Yang et al. investigated the ecorestoration of quarry wastelands by planting Indigofera amblyantha Craib as the main species. The results suggested that Indigofera amblyantha Craib was beneficial to microbial diversity in soil compared with other shrub species [80]. Wu et al.'s research result showed that the arbuscular mycorrhizal (AM) fungi were easy to infect the root of Indigofera amblyantha Craib, and the infection rate reached $80.2 \%$. The abundance of Glomus liquidambaris, Acaulospora aporocarpia, and Acaulospora scrobiculata were relatively higher [81]. The AM infection could significantly improve the uptake of phosphorus nutrients in low phosphorus soils [81]. It was worth noting that the formed AM-symbiotic structure with the ability to fixate and isolate heavy metals reduced the transport of heavy metals from roots to the ground [82]. For example, the AM reduced the transport of $\mathrm{Zn}, \mathrm{Cd}, \mathrm{As}, \mathrm{Cr}$, and $\mathrm{Cu}$ to the aboveground part of the plant $[83,84]$. On the whole, the microbial communities in rhizosphere soils may be an important favorable factor contributing to their adaptability.

4.4. Tolerance of Heavy Metals. Tang et al. planted the Indigofera amblyantha Craib in the tungsten mine site for ecological restoration. Through the analysis of heavy metals in the soil, it was inferred that the absorption of $\mathrm{Cu}, \mathrm{Zn}$, and As was relatively significant [33]. Yin et al. found that the $\mathrm{Cu}$ content of the soil in used Indigofera amblyantha Craib ecorestoration in the abandoned quarry was lower than that of other species and suggested it had a good enrichment capacity for $\mathrm{Cu}$ [85]. Their findings confirmed that Indigofera amblyantha Craib had a good capacity of accumulation and transport of $\mathrm{Cu}$ and $\mathrm{Zn}$ from stone mines in this study. Chen et al. reported results suggested that Indigofera amblyantha Craib had moderate tolerance and bioaccumulation capability for $\mathrm{Pb}$ and $\mathrm{Cd}[34,35]$. However, there was no advantage of Indigofera amblyantha Craib on accumulative, transport, and tolerance to $\mathrm{Pb}$ was found in this study. Besides, there was no research related to heavy metals in Indigofera amblyantha Craib. Although Indigofera amblyantha Craib does not meet the standard of heavy metal super accumulation plant, it still can be used for the ecological restoration of soil contaminated by $\mathrm{Cd}, \mathrm{Cu}, \mathrm{Zn}$, 


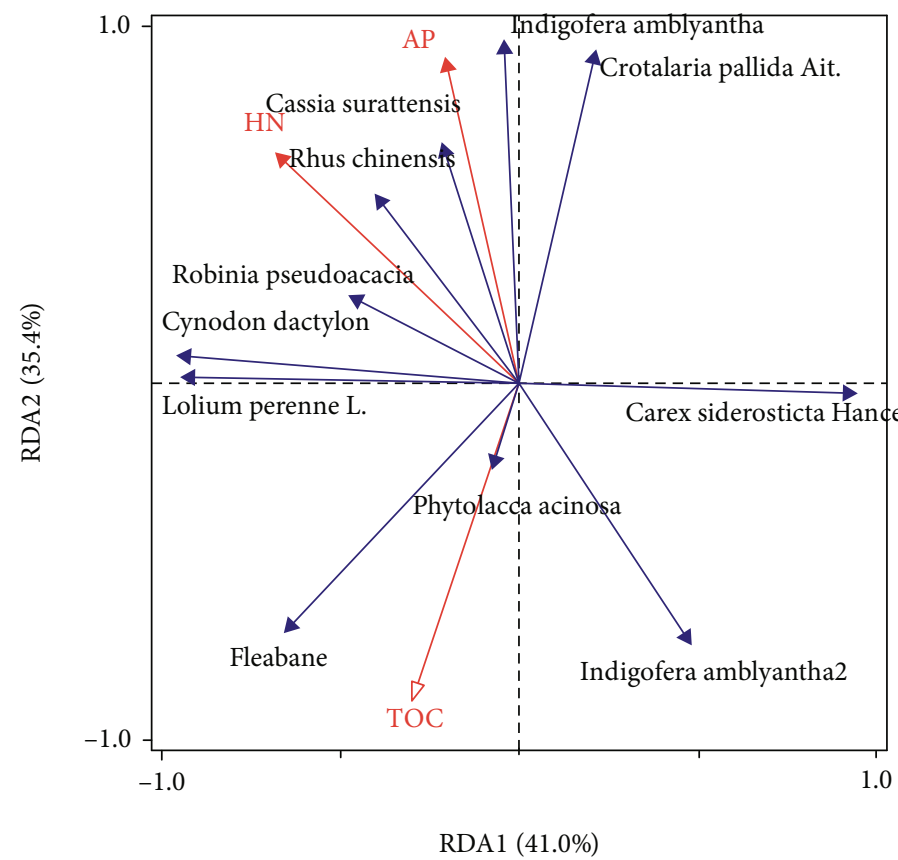

(a)

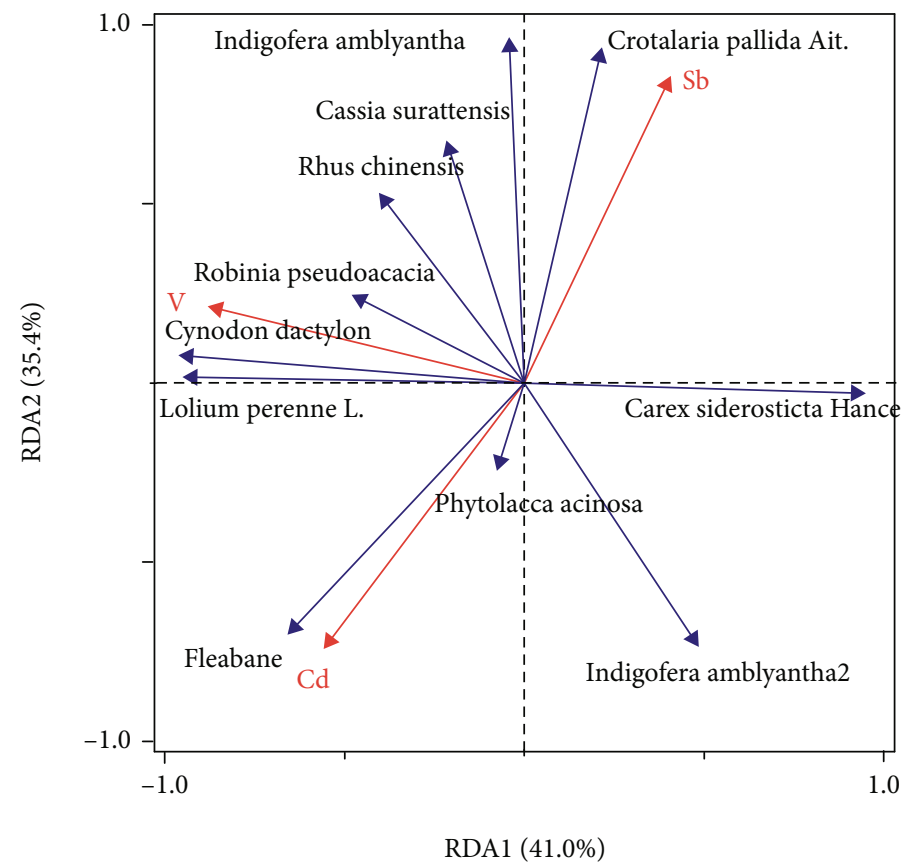

(b)

FIgURE 4: The RDA ranking diagram of species importance values and factors in substrate material. (a) nutrient factors and (b) heavy metals in the artificial soil matrix. Solid arrows represent species information and hollow arrows represent environmental factors. The testing and stepwise selection method: summarize effects of explained variables and unrestricted permutations.

and $\mathrm{Mn}$ or mining areas due to its strong enrichment and transport capacity for $\mathrm{Cd}, \mathrm{Cu}, \mathrm{Zn}$, and $\mathrm{Mn}$ and its large biomass.

\section{Conclusions}

In this study, Indigofera amblyantha Craib has shown great adaptability based on two years of follow-up investigation on eco-restoration engineering in expose slopes of the stone coal mines. We studied the factors related to plants growth and their influence on important values (IV) of plants used in the eco-restoration. These important factors included $\mathrm{pH}$, nutrient elements ( $, \mathrm{P}, \mathrm{K}$, and TOC), heavy metals in substrate material with recovered time, and the composition of microbial communities in rhizosphere soils. The dominant species Indigofera amblyantha Craib showed a positive 
correlation with $\mathrm{HN}, \mathrm{AP}, \mathrm{V}$, and $\mathrm{Sb}$, and negative with TOC and $\mathrm{Cd}$ by the redundancy analysis (RDA). Meanwhile, Indigofera amblyantha Craib had a better ability to enrich and transfer $\mathrm{Cd}, \mathrm{Cu}, \mathrm{Zn}$, and $\mathrm{Mn}$ and with a good tolerance to $\mathrm{Pb}, \mathrm{Sb}, \mathrm{V}$, and $\mathrm{Cr}$. Furthermore, the root of Indigofera amblyantha Craib could form distinct nodules, and its composition of microbial communities in rhizosphere soils was different from that of other plants. Indigofera amblyantha Craib was also beneficial to microbial diversity in soil compared with other shrub species. In addition to its drought-tolerant and barren-tolerant characteristics, these factors were helpful to explain the adaptability of Indigofera amblyantha Craib in the eco-restoration of stone coal mines. Overall, the results of this study could shed light on the applicability of Indigofera amblyantha Craib in ecorestoration engineering of mining areas.

\section{Data Availability}

All data generated or analyzed during this study are included in this article.

\section{Conflicts of Interest}

The authors declare that they have no conflicts of interest.

\section{Acknowledgments}

Funding from the Science and Technology Innovation Program of Hunan Province (2020RC2053), Hunan Provincial Key R\&D (2018WK4007), the Open Fund from the State Key Laboratory of Hydraulics and Mountain River Engineering (SKHL2009), and the Double First-class construction project of Hunan Agricultural University (SYL201802005) is gratefully acknowledged.

\section{Supplementary Materials}

Supplementary Material provides the detailed description for ecological engineering, collection and preparation of samples, and analytical and calculations of data. And the Tables and Figures in Supplementary Material help to explain the content of the Manuscript. (Supplementary Materials)

\section{References}

[1] Y.-M. Zhang, S.-X. Bao, T. Liu, T.-J. Chen, and J. Huang, “The technology of extracting vanadium from stone coal in China: history, current status and future prospects," Hydrometallurgy, vol. 109, no. 1-2, pp. 116-124, 2011.

[2] S. Dai, X. Zheng, X. Wang et al., "Stone coal in China: a review," International Geology Review, vol. 60, no. 5-6, pp. 736-753, 2018.

[3] X. Yang, Y. Zhang, S. Bao, and C. Shen, "Separation and recovery of vanadium from a sulfuric-acid leaching solution of stone coal by solvent extraction using trialkylamine," Separation and Purification Technology, vol. 164, pp. 49-55, 2016.

[4] F. Wang, Y. Zhang, T. Liu et al., "A mechanism of calcium fluoride-enhanced vanadium leaching from stone coal," Inter- national Journal of Mineral Processing, vol. 145, pp. 87-93, 2015.

[5] B. Yan, D. Wang, L. Wu, and Y. Dong, "A novel approach for pre-concentrating vanadium from stone coal ore," Minerals Engineering, vol. 125, pp. 231-238, 2018.

[6] D. He, Q. Feng, G. Zhang, L. Ou, and Y. Lu, "An environmentally-friendly technology of vanadium extraction from stone coal," Minerals Engineering, vol. 20, no. 12, pp. 1184-1186, 2007.

[7] S. Ning and R. Ma, "Exploitation and development of vanadium extraction from stone coal in China," Mining and Metallurgical Engineering, vol. 32, no. 5, pp. 57-61, 2012.

[8] P. Hu, Y. Zhang, T. Liu, J. Huang, Y. Yuan, and Q. Zheng, "Highly selective separation of vanadium over iron from stone coal by oxalic acid leaching," Journal of Industrial and Engineering Chemistry, vol. 45, pp. 241-247, 2017.

[9] M. Petranikova, A. H. Tkaczyk, A. Bartl, A. Amato, V. Lapkovskis, and C. Tunsu, "Vanadium sustainability in the context of innovative recycling and sourcing development," Waste Management, vol. 113, no. 15, pp. 521-544, 2020.

[10] J.-C. Lee, Kurniawan, E.-y. Kim, K. W. Chung, R. Kim, and H.-S. Jeon, "A review on the metallurgical recycling of vanadium from slags: towards a sustainable vanadium production," Journal of Materials Research and Technology, vol. 12, pp. 343364, 2021.

[11] A. O. Omotehinse and B. D. Ako, "The environmental implications of the exploration and exploitation of solid minerals in Nigeria with a special focus on Tin in Jos and Coal in Enugu," Journal of Sustainable Mining, vol. 18, no. 1, pp. 1824, 2019.

[12] B. U. Choudhury, A. Malang, R. Webster et al., "Acid drainage from coal mining: effect on paddy soil and productivity of rice," Science of the Total Environment, vol. 583, pp. 344351, 2017.

[13] V. Masindi and K. L. Muedi, "Environmental contamination by heavy metals," Heavy Metals, vol. 10, pp. 115-132, 2018.

[14] S. Park, M. Choi, D. Jang, D. Joe, and K. Park, "Distribution and sources of dissolved and particulate heavy metals (Mn, $\mathrm{Co}, \mathrm{Ni}, \mathrm{Cu}, \mathrm{Zn}, \mathrm{Cd}, \mathrm{Pb}$ ) in Masan Bay, Korea," Ocean Science Journal, vol. 55, no. 1, pp. 49-67, 2020.

[15] H. Lin, G. Li, Y. Dong, and J. Li, "Effect of $\mathrm{pH}$ on the release of heavy metals from stone coal waste rocks," International Journal of Mineral Processing, vol. 165, pp. 1-7, 2017.

[16] M. Song, Y. Hu, C. Huang, and Z. Zhou, "Study on the release rate of $\mathrm{Cd}, \mathrm{Pb}$ from stone coal under leaching conditions of different pH values," Geochimica, vol. 40, no. 6, pp. 588-595, 2011.

[17] Y.-B. Dong, Y. Liu, and H. Lin, "Leaching behavior of V, Pb, $\mathrm{Cd}, \mathrm{Cr}$, and As from stone coal waste rock with different particle sizes," International Journal of Minerals, Metallurgy, and Materials, vol. 25, no. 8, pp. 861-870, 2018.

[18] X.-y. Xiao, M. Yang, Z.-h. Guo, Z.-c. Jiang, Y.-n. Liu, and $\mathrm{X}$. Cao, "Soil vanadium pollution and microbial response characteristics from stone coal smelting district," Transactions of Nonferrous Metals Society of China, vol. 25, no. 4, pp. 12711278, 2015.

[19] D. Tao, D. Wang, Y. Bai, and Z. Zhang, "Optimizing the formulation of coal gangue planting substrate using wastes: The sustainability of coal mine ecological restoration," Ecological Engineering, vol. 143, p. 105669, 2020. 
[20] E. Sandell Festin, C. Salk, M. Tigabu, S. Syampungani, and P. Christer Odén, "Biological traits of tropical trees suitable for restoration of copper- polluted lands," Ecological Engineering, vol. 138, pp. 118-125, 2019.

[21] M. I. Masarei, T. E. Erickson, D. J. Merritt, R. J. Hobbs, and A. L. Guzzomi, "Engineering restoration for the future," Ecological Engineering, vol. 159, p. 106103, 2021.

[22] M. S. Li, "Ecological restoration of mineland with particular reference to the metalliferous mine wasteland in China: a review of research and practice," Science of the Total Environment, vol. 357, no. 1-3, pp. 38-53, 2006.

[23] K. Lei, H. Pan, and C. Lin, "A landscape approach towards ecological restoration and sustainable development of mining areas," Ecological Engineering, vol. 90, pp. 320-325, 2016.

[24] J. A. Cooke and M. S. Johnson, "Ecological restoration of land with particular reference to the mining of metals and industrial minerals: a review of theory and practice," Environmental Reviews, vol. 10, no. 1, pp. 41-71, 2002.

[25] H. Xu, T.-B. Li, J.-N. Chen, C.-N. Liu, X.-H. Zhou, and L. Xia, "Characteristics and applications of ecological soil substrate for rocky slope vegetation in cold and high-altitude areas," Science of the Total Environment, vol. 609, pp. 446-455, 2017.

[26] N. L. Chau and L. M. Chu, "Revegetation of subtropical soil slopes: groundcover performance and the implications of urban development and slope features on plant community," Applied Vegetation Science, vol. 21, no. 4, pp. 658-668, 2018.

[27] S. Dan, X. En-De, R. Hao, L. Yan-Ping, and Z.-Q. Liang, "Ecological restoration of different vegetation collocations of coal mine dump in typical steppe," Chinese Journal of Ecology, vol. 38, no. 2, p. 336, 2019.

[28] K. T. Schmidt, M. Maltz, P. Ta et al., "Identifying mechanisms for successful ecological restoration with salvaged topsoil in coastal sage scrub communities," Diversity, vol. 12, no. 4, p. 150, 2020.

[29] P. Madejón, D. Caro-Moreno, C. M. Navarro-Fernández, S. Rossini-Oliva, and T. Marañón, "Rehabilitation of waste rock piles: impact of acid drainage on potential toxicity by trace elements in plants and soil," Journal of Environmental Management, vol. 280, p. 111848, 2021.

[30] Y. Sun, X. Gu, and X. Xu, "Ecological restoration and mechanical reinforcement effect of slope of tailings reservoir," Environmental Earth Sciences, vol. 80, no. 3, pp. 1-12, 2021.

[31] I. Rashid, S. M. Haq, J. J. Lembrechts, A. A. Khuroo, A. Pauchard, and J. S. Dukes, "Railways redistribute plant species in mountain landscapes," Journal of Applied Ecology, vol. 58, no. 9, pp. 1967-1980, 2021.

[32] L. Zhang, M. Li, and B. Zhao, "Experimental study on tensile properties and reinforcement ability of plant roots," Nature, Environment and Pollution Technology, vol. 17, no. 3, 2018.

[33] H. Tang, X. Cao, and X. Li, "Absorption and accumulation of heavy metals by 5 plants," Science Technology and Engineering, vol. 15, no. 15, pp. 103-106, 2015.

[34] Z. Chen, X. Liu, Y. Ai et al., "Effects and mechanisms of revegetation modes on cadmium and lead pollution in artificial soil on railway rock-cut slopes," Science of the Total Environment, vol. 644, pp. 1602-1611, 2018.

[35] Z. Chen, Y. Ai, C. Fang et al., "Distribution and phytoavailability of heavy metal chemical fractions in artificial soil on rock cut slopes alongside railways," Journal of Hazardous Materials, vol. 273, pp. 165-173, 2014.

[36] H. Freitas, M. N. V. Prasad, and J. Pratas, "Plant community tolerant to trace elements growing on the degraded soils of
Sao Domingos mine in the south east of Portugal: environmental implications," Environment International, vol. 30, no. 1, pp. 65-72, 2004.

[37] S. Li, Y. Li, J. Shi, T. Zhao, and J. Yang, "Optimizing the formulation of external-soil spray seeding with sludge using the orthogonal test method for slope ecological protection," Ecological Engineering, vol. 102, pp. 527-535, 2017.

[38] K. Singh, V. C. Pandey, and R. P. Singh, "Cynodon dactylon: An efficient perennial grass to revegetate sodic lands," Ecological Engineering, vol. 54, pp. 32-38, 2013.

[39] R. Li, S. Kan, M. Zhu et al., "Effect of different vegetation restoration types on fundamental parameters, structural characteristics and the soil quality index of artificial soil," Soil and Tillage Research, vol. 184, pp. 11-23, 2018.

[40] J. Qin, W. Xi, A. Rahmlow, H. Kong, Z. Zhang, and Z. Shangguan, "Effects of forest plantation types on leaf traits of_Ulmus pumila_ and_Robinia pseudoacacia_on the Loess Plateau, China," Ecological Engineering, vol. 97, pp. 416-425, 2016.

[41] B. B. Lamont, S. Downes, and J. E. Fox, "Importance-value curves and diversity indices applied to a species-rich heathland in Western Australia," Nature, vol. 265, no. 5593, pp. 438-441, 1977.

[42] Ministry of Agriculture of the People's Republic of China, Method for determination of soil organic matter, Standard Press, Beijing; China, 2006.

[43] National environmental protection standards of the People's Republic of China, Soil-determination of total phosphorus by alkali fusion-Mo-Sb anti spectrophotometric method, Environmental Protection Department, Beijing, 2011.

[44] Ministry of Agriculture of the People's Republic of China, Soil testing part 7: method for determination of available phosphorus in soil, Beijing:China Standard Press, Beijing, 2015.

[45] Ministry of Agriculture of the People's Republic of China, Determination of total nitrogen in soil-automatic kjeldahl apparatus method, China Standard Press, Beijing, 2012.

[46] State Forestry Administration, Nitrogen determination methods of forest soils, China Standard Press, Beijing, 2015.

[47] F. Wei, Modern analytical methods of soil elements, Chinese Environmetal Science Press, Beijing, 1992.

[48] Ministry of Agriculture of the People's Republic of China, "Determination of exchangeable potassium and non-exchangeable potassium content in soil," China Standard Press, Beijing, 2004.

[49] A. Modi, S. Vai, D. Caramelli, and M. Lari, "The illumina sequencing protocol and the NovaSeq 6000 system," Methods in Molecular Biology, vol. 2242, pp. 15-42, 2021.

[50] C. J. Ter Braak and P. Smilauer, Canoco reference manual and user's guide: software for ordination, version 5.0, Microcomputer Power, 2012.

[51] A. L. Aradottir and D. Hagen, "Ecological restoration: approaches and impacts on vegetation, soils and society," Advances in Agronomy, vol. 120, pp. 173-222, 2013.

[52] M. A. Pavao-Zuckerman, "The nature of urban soils and their role in ecological restoration in cities," Restoration Ecology, vol. 16, no. 4, pp. 642-649, 2008.

[53] J.-L. Liang, J. Liu, P. Jia et al., "Novel phosphate-solubilizing bacteria enhance soil phosphorus cycling following ecological restoration of land degraded by mining," The ISME Journal, vol. 14, no. 6, pp. 1600-1613, 2020.

[54] A. Król, K. Mizerna, and M. Bożym, "An assessment of $\mathrm{pH}$-dependent release and mobility of heavy metals from 
metallurgical slag," Journal of Hazardous Materials, vol. 384, p. 121502, 2020.

[55] Y. J. du, M.-L. Wei, K. R. Reddy, Z.-P. Liu, and F. Jin, "Effect of acid rain $\mathrm{pH}$ on leaching behavior of cement stabilized leadcontaminated soil," Journal of Hazardous Materials, vol. 271, pp. 131-140, 2014.

[56] R. T. Amos, D. W. Blowes, L. Smith, and D. C. Sego, "Measurement of wind-induced pressure gradients in a waste rock pile," Vadose Zone Journal, vol. 8, no. 4, pp. 953-962, 2009.

[57] S. Mickovski and L. P. H. van Beek, “A decision support system for the evaluation of eco-engineering strategies for slope protection," Geotechnical \& Geological Engineering, vol. 24, no. 3, pp. 483-498, 2006.

[58] Z. Bai, L. Ma, S. Jin et al., "Nitrogen, phosphorus, and potassium flows through the manure management chain in China," Environmental Science \& Technology, vol. 50, no. 24, pp. 13409-13418, 2016.

[59] C. A. Mcclaugherty, J. Pastor, J. D. Aber, and J. M. Melillo, "Forest litter decomposition in relation to soil nitrogen dynamics and litter quality," Ecology, vol. 66, no. 1, pp. 266275, 1985.

[60] P.-L. Hu, S.-J. Liu, Y.-Y. Ye, W. Zhang, K.-L. Wang, and Y. R. $\mathrm{Su}$, "Effects of environmental factors on soil organic carbon under natural or managed vegetation restoration," Land Degradation \& Development, vol. 29, no. 3, pp. 387-397, 2018.

[61] Y. Liu, H.-T. Miao, X. Chang, and G. L. Wu, "Higher species diversity improves soil water infiltration capacity by increasing soil organic matter content in semiarid grasslands," Land Degradation \& Development, vol. 30, no. 13, pp. 1599-1606, 2019.

[62] M. Guo, F. Zheng, W. He, S. An, L. Yu, and J. An, "Variation of vegetation diversity and its relationship with soil nutrient and enzyme activity in lands of different abandoned years in the loess hilly-gully region," Acta Pedologica Sinica, vol. 47, no. 5, pp. 979-986, 2010.

[63] R. Adeleke, C. Nwangburuka, and B. Oboirien, "Origins, roles and fate of organic acids in soils: a review," South African Journal of Botany, vol. 108, pp. 393-406, 2017.

[64] Q. T. Dinh, Z. Li, T. A. T. Tran, D. Wang, and D. Liang, "Role of organic acids on the bioavailability of selenium in soil: a review," Chemosphere, vol. 184, pp. 618-635, 2017.

[65] M. Hartmann and F. Widmer, "Community structure analyses are more sensitive to differences in soil bacterial communities than anonymous diversity indices," Applied and Environmental Microbiology, vol. 72, no. 12, pp. 7804-7812, 2006.

[66] N. Fanin, P. Kardol, M. Farrell et al., "Effects of plant functional group removal on structure and function of soil communities across contrasting ecosystems," Ecology Letters, vol. 22, no. 7, pp. 1095-1103, 2019.

[67] S. Wang, X. Zuo, X. Zhao et al., "Dominant plant species shape soil bacterial community in semiarid sandy land of northern China," Ecology and Evolution, vol. 8, no. 3, pp. 1693-1704, 2018.

[68] Y. Zeng, C. Zhao, Z. W. Kundzewicz, and G. Lv, "Distribution pattern of Tugai forests species diversity and their relationship to environmental factors in an arid area of China," PLoS One, vol. 15 , no. 5, article e0232907, 2020.

[69] I. U. Rahman, F. Ijaz, Z. Iqbal et al., "A novel survey of the ethno medicinal knowledge of dental problems in Manoor Valley (Northern Himalaya), Pakistan," Journal of Ethnopharmacology, vol. 194, pp. 877-894, 2016.

[70] L. Xu, C. Naidong, Z. Shoubiao, L. Houqi, and C. Xie, "Development and utilization of plants of Indigofera in Anhui Prov- ince," Forest By-Product and Speciality in China, vol. 1, pp. 6466, 2007.

[71] B. Wang, F.-B. Song, and J.-C. Zhang, "Advances in study of salt-stress tolerance in plants," System Sciences and Comprehensive Studies in Agriculture, vol. 2, 2007.

[72] W. E. Wang, Y. Li, S. Nong, and W. C. Yu, "The effects of salt stress on seed germination of Indigofera amblyantha," Hubei Agricultural Sciences, vol. 50, pp. 321-324, 2011.

[73] L. Zhang, Z. Xia, W. Xu et al., "A study on pullout test of root subjected to axial load," Nature, Environment and Pollution Technology, vol. 19, no. 2, pp. 441-452, 2020.

[74] P. Xu and J. Wang, "Drought resistance of slope pioneer plant Magnolia multiflora," Agricultural Science and Technology, vol. 17, no. 9, pp. 2037-2041, 2016.

[75] Q.-Y. Zhang, L.-X. Tang, H.-G. Liao, L. Pan, L. Chen, and T.L. Huang, "Effect of microstructure in cross section on tensile properties of $<\mathrm{i}>$ Indigofera amblyantha $</ \mathrm{i}>$," Chinese Journal of Plant Ecology, vol. 43, no. 8, pp. 709-717, 2019.

[76] Y. Zhao, X. Hu, H. Li, C. Liu, G. Li, and H. Zhu, "Characteristics of slope soil shear strength reinforced by shrub roots in cold and arid environments," Transactions of the Chinese Society of Agricultural Engineering, vol. 32, no. 11, pp. 174-180, 2016.

[77] J. Wan, H. Xiao, and J. He, "Tensile properties of Magnolia multiflora's roots and solpe stability analysis," Journal of Huazhong University of Science and Technology (Natural Science Edition), vol. 8, pp. 110-116, 2014.

[78] Y. Yang, Z. Xia, and H. Xiao, "Experimental research on shear strength of Indigofera amblyantha root-soil composite," Journal of Yangtze River Scientific Research Institute, vol. 31, no. 4, pp. 72-76, 2014.

[79] Y. Xi, L. Zhao, X. Wang, Q. Wang, and C. Chen, "Investigation and analysis of root nodule resources of wild Indigofera amblyantha in rocky desertification areas," China Environmental Science, vol. 39, no. 10, pp. 4409-4415, 2019.

[80] Y. Xu, Q. Zeng, T. Bai, X. Yin, and L. Wang, "Effects of different vegetation restoration patterns on soil microbial quantity of the abandoned quarries," Guizhou Agricultural Sciences, vol. 44, no. 6, pp. 167-171, 2016.

[81] T. Wu, H.-Y. Yao, B.-T. Mo, Z. Long, and C. Luo, “The category and distribution of arbuscular mycorrhizal fungi from the rhizosphere of eight cultivated leguminous shrubs. Pratacultural science," Pratacultural Science (China), vol. 33, no. 2, pp. 210-218, 2016.

[82] G. Duan, H. Cui, Y. Yang, X. Yi, D. Zhu, and Y. Zhu, "Interactions among soil biota and their applications in synergistic bioremediation of heavy-metal contaminated soils," Chinese Journal of Biotechnology, vol. 36, no. 3, pp. 455-470, 2020.

[83] B. D. Chen, Y.-G. Zhu, J. Duan, X. Y. Xiao, and S. E. Smith, "Effects of the arbuscular mycorrhizal fungus _Glomus mosseae_on growth and metal uptake by four plant species in copper mine tailings," Environmental Pollution, vol. 147, no. 2, pp. 374-380, 2007.

[84] S. Wu, X. Zhang, B. Chen et al., "Chromium immobilization by extraradical mycelium of arbuscular mycorrhiza contributes to plant chromium tolerance," Environmental and Experimental Botany, vol. 122, pp. 10-18, 2016.

[85] X. Yin, L. Tang, Q. Zeng, B. Lin, Y. Zhao, and Y. Xu, "Distribution and pollution assessment of heavy metals in soils after artificial vegetation restoration in abandoned quarries in Huangshi," Hubei Forestry Science and Technology, vol. 47, pp. 34-38, 2018. 